\title{
A Cytotaxonomtic Comparison of Parsley and Celery
}

\author{
by Minosuke Hiroe*
}

広江美之助：パースレーとセルッーの細胞分類学比較

\section{Received April 9, 1955}

In 1814, Hoffman established the genus Petroselinum based on Apium Petroselinum L. The principal reason advanced was that in Apium the petals are white, while in Petroselinum they are very light green. The writer believes that petal color is likely to be of very little taxonomic value.

In species of the genus Apium, especially Apium Petroselinum L., the lateral branches appear to be the axis, forming a monopodial sympodium, while the true stem apex produces an inflorescence. In many Umbelliferae, on the other hand, growth is by quite ordinary monopodial branching. The fruit of the genus Apium is small and ovoid or orbicular. Both Apium graveolens (celery) and A. Petroselinum (parsley) contain the glucoside characteristic of Apium.

From a study of Apium Petroselinum, Ogawal) concluded that the chromosone number is $n=11$. Recently, Wanscher ${ }^{2)}$ reported Apium graveolens to possess the chromosome number of $n=11$, also. In the present cytological observations on the root-tip cells of $A$. Petroselinum and $A$. graveolens (based upon plants cultivated in the Botanical Gardens of Kyoto University, Japan), it has been noted that metaphase plates show $2 n=22$ (Figs. I-VI). Karyotype analysis of the two species showed that metaphase chromosomes comprise two sets of 11 chromosomes (Figs. II, IV-VI). Through observation of the karyotypes (Figs. II, IV) and idiograms (Figs. V-VI) indicates that there is a relationship of chromosome morphology between the two species.

From the fact that $A$. Petroselinum and A. graveolens have very similar morphological characters, but are different in the karyotypes, it may be assumed that they are closely related taxa. I wish, therefore, to express this relationship by placing them together in the same genus.

Involucel conspicuous; petals light green; node of radical leaf with 11 leaf gaps Apium Petroselinum

Involucel wanting; petals white; node of radical leaf with 19 leaf gaps Apium graveolens

Apium Petroselinum L. Sp. P1. 264. 1753. Synonyms: Apium crispum Mill. Gard. Dict. ed. 8, Apium no. 2. 1768., Petroselinum hortense Hoffm. Gen. Umbell. 163.

\footnotetext{
* Department of Botany, Faculty of Science, Kyoto University, Kyoto, Japan. 京都大学理学部植物 学教窒
} 


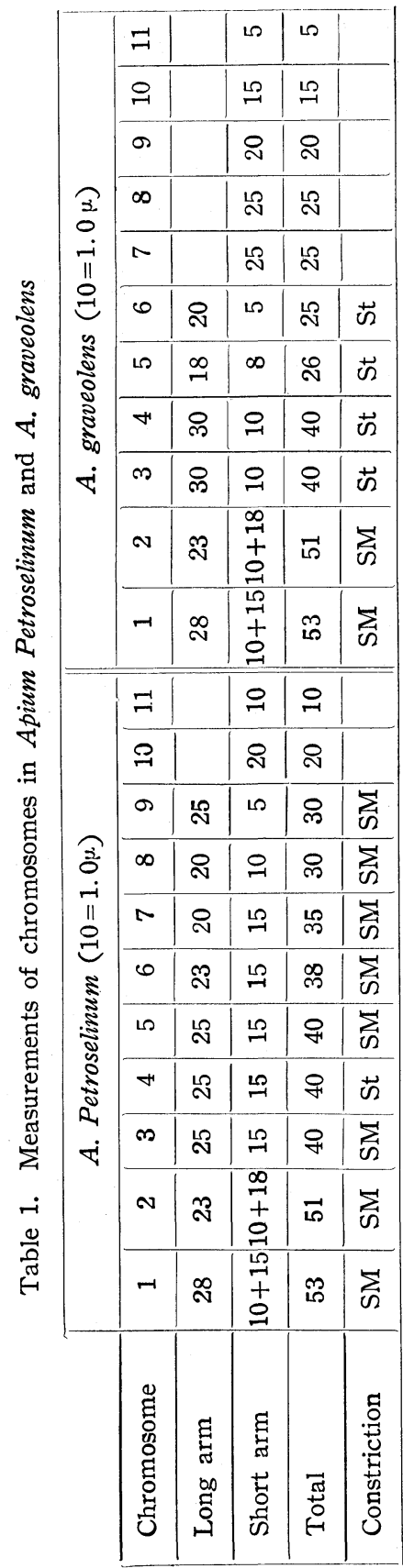

1814, Petroselinum sativum Hoffm., op. cit., 177, Petroselinum vulgare Lag. Amen. Nat. 103. 1821, Carum Petroselinum Benth. \& Hook. Gen. P1. 1: 891. 1867, Petroselinum crispum (Mill.) Nyman ex Kew Hand-list Herbac. P1. 3, 122. 1925.

Type locality: “In Sardinia juxta seaturigines." Distribution : Central and northern Europe; adventive in America and Japan. The plant is cultivated as a vegetable. The karyotype analysis of this species may be depicted as follows:

$$
\begin{aligned}
K(2 n)=22=2^{\mathrm{CS}} \mathrm{A}^{\mathrm{SM}}+2^{\mathrm{CS}} \mathrm{B}^{\mathrm{SM}}+2 \mathrm{C}^{\mathrm{SM}}+2 \mathrm{D}^{\mathrm{St}} \\
+10 \mathrm{E}^{\mathrm{SM}}+4 \mathrm{~F}
\end{aligned}
$$

The lengths of the chromosomes of $A$. graveolens and $A$. Petroselinum are shown below:

Apium graveolens $\mathrm{L}$. Sp. Pl.264.1753. Synonyms: Apium integrilobum Hayata, Mater. Fl. Formosa 126. 1911.

Type locality: Europe. This has a wide range in Europe, North Africa, America (adventive), and western Asia to northwestern India, also in Japan; the plant is cultivated for use as a vegetable.

B. Hayata recorded Apium integrilobum according to the specimen collected by U. Faurie 122, " in humidis Maruyama, Taipeh, Formasa”. The writer, after careful examination of the isotype and many other specimens in the type locality of this plant, concludes that $A$. integrilobum is merely a specimen of $A$. graveolens grown in barren soil. The karyotype analysis of this species may be depicted as follows:

$$
K(2 n)=22=2^{\mathrm{CS}} \mathrm{A}^{\mathrm{SM}}+2 \mathrm{~B}^{\mathrm{SM}}+8 \mathrm{C}^{\mathrm{St}}+8 \mathrm{D}+2 \mathrm{E}
$$

The writer expresses his cordial thanks $\mathrm{t} 2$ Prof. S. Kitamura and Prof. L. Constance (University of California, U.S. A.) for their guidance, and to Prof. M. Shigenaga for his guidance in the cytological technique.

\section{Literature Cited}

1. Ogawa, Mem. Coll. Sci. Kyoto Univ. 4: Fig. b, 311 (1929) 2. Wanscher, Hereditas 15: Fig. 8, 180 (1931) 

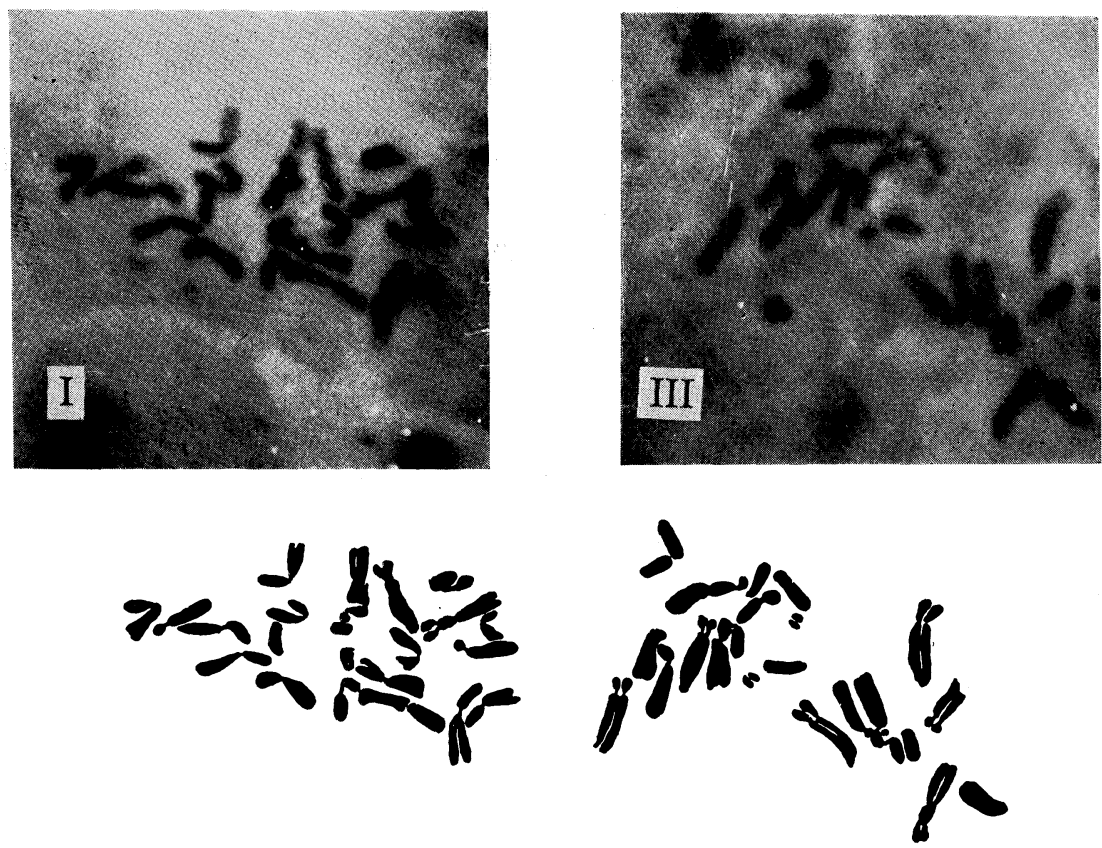

II

IV
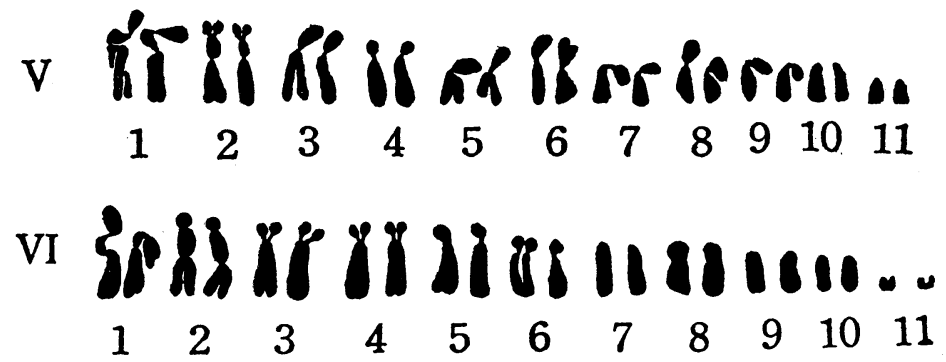

Figs. I-VI, Metaphase chromosomes in root-tip cells of Aptum Petroselinum L. and Apium graveolens L. taken with a imm. obj. (n. A. 1.25) and a periplane oc. of C. Zeiss and magnified by $\times 2000$ (pretreated with 8 -Oxyquinoline and stained with Orsein).

Figs. I-II, Somatic chromosomes $(2 n=22)$ of Apium Petroselinum L. Fig. I, Photomicrograph of metaphase plate. Fig. II, Schematic reproduction of Fig. I.

Figs. III-IV, Somatic chromosomes $(2 n=22)$ of Apium graveolens L. Fig. III, Photomicrograph of metaphase plate. Fig. IV, Schematical reproduction of Fig. III.

Fig. V, Chromosome idiograms of A. Petroselinum L.

Fig. VI, Chromosome idiograms of $A$. graveolens L. 